\title{
ビディコンについて
}

日本放送劭合技術研究䄬

松山喜八郎

\section{文 栽}

(1) P. K. Weimer, S.V. Forgue \& R. R. Goodrich ;

The Vidicon Photoconductive Camera Tube, Electronics, may, 1950.

(2) R.C.Webb; J.M. Morgan :

"Simplified Television for industry"

Electronics, June, 1950.

（1）緒杗

アイコ/スコープ.オルシコン及びイメージオルシコン笋は、何れも

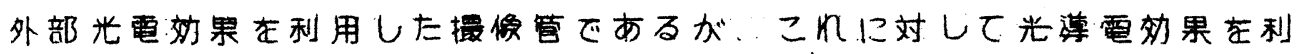
用した最站の高感庋撮倣管在RCAでVidiconと稻している。

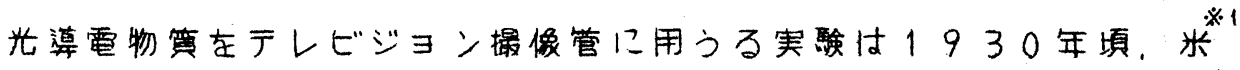

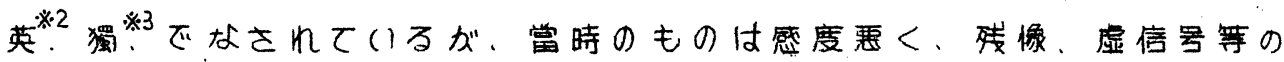

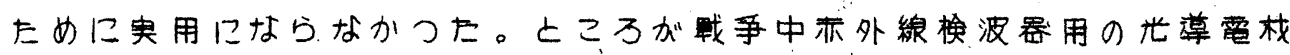
料に関する研究加盛んに行历れ、その結果これを撮像管口用方る基硭加 確立された。

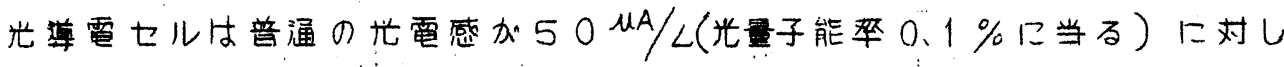

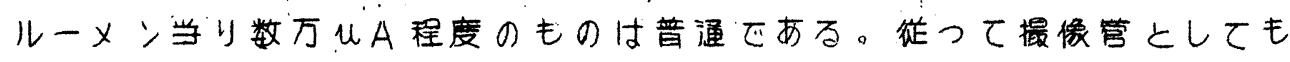
高感度のもの加出來れば、イメージオルションのような multiplier も. imagesectionも不巡要口なる。

(2) 1. 吋 ビディコン

エ㘧用に利用するため制作した小型ビ示イコンは外管の直径1时。長 
己。时である。第1四は動依回路の略四、第2四は棈营を示している。 2 区几示したよう口光尊電物筧汃透明金属の上口全布してあつて，これ を走查するビームはオルシコン型の低速度でもよければ、又ァイコノス コープのような動作にしでもよい, wallscreenはターゲットの前方に 一恢なフイールド考与えるに役立つ。

\section{（3）信号 発生機構}

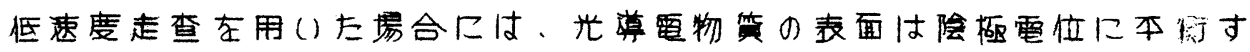

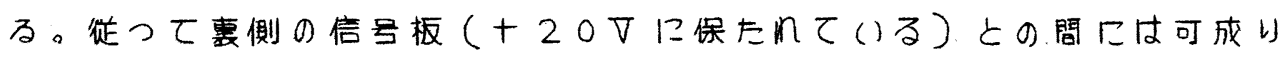

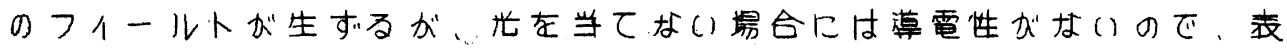
面と裹面との間には電流汃流れない。

ところが光を当てるとその強弱に比例して導要性を增すので、走查固 期（ $\frac{1}{30}$ 秒）の間口表面は1〜2マ正ロなる。ビームが再びこの上を走查 すると、この電位を陰極電位汽引宥すのだ、信局を発生することになる。

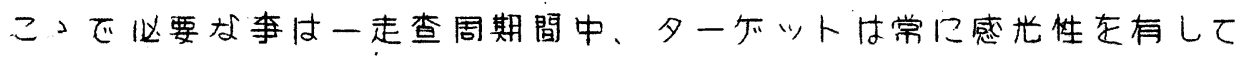
(て、電何の蓄樍定行い得るようになつていることである。 その時定数は $\frac{1}{30}$ 秒より大きく、暗( 时の抵抗は $10^{12} \mathrm{ohm}-\mathrm{cm}$ 以上这 である。

栈料としては、セレニウム、硫黄、硫化物、セレン化物、酸化物等た

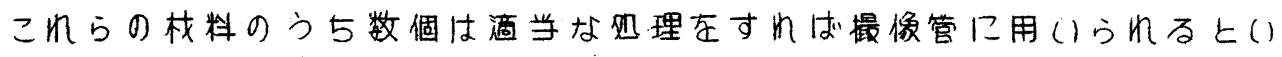

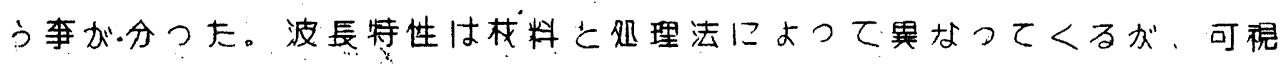

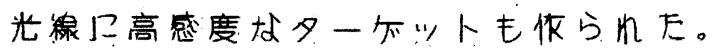

（4）動作 特 性

虚信号もなく又初期になやまされたような timelagもな(1。又、

$1000 \mu \mathrm{A} / \mathrm{L}$ : 以上のもの毛得及事加出及。1时ビデイコンは600 本以上の解像力を有せしめる事汃出亦る。同㥞极修件のもとではこれよ り大き(1イメージオルシコンは約1500本になる。

ターケットの容量は充分大きしのでhighligbtに於ける出力信号の $S / N$ は充大をい。

信号对光の強さの特性はオルシコンと同硨にLow lightに於ては直 線的であるが、highlightでは少し本らになる。そしてイメージオルシ

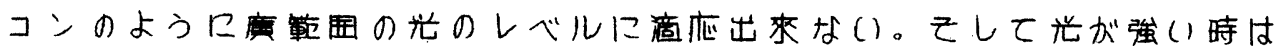


コントラストが悪る()。

ビデイコの利卓は、イメージオルシコンよリ動作の調籍加非常に筬

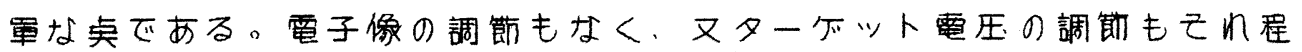

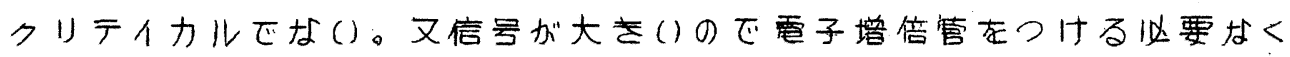

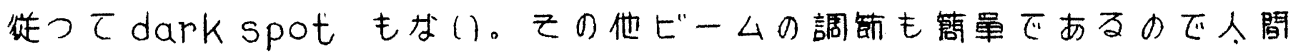
がタッチ出來ない所のような工前上の尤用が廣( 。

然してら，ビテイコンの毒命、特口許容温度制报、結果の再摆性の問 題は、害䄞の工業上の使用口对して今後尚大(口研究され败はならぬし 尚又timelagの問題も実験の途上にある。
(5) 感
度

1 吋ビデイコンは $300 \mu \mathrm{A} /\llcorner$ 、 $f=2$ をい、数フートランベルト

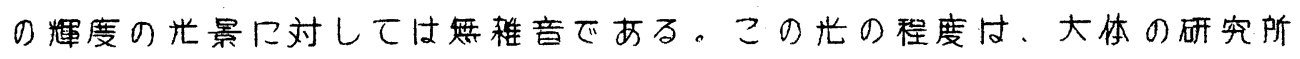
或は工場に於ける光のレべルより低(から特别の㮩明を必要としない。

感庋をイメージオルシコンと此較すると、敏フートランベルト程度の

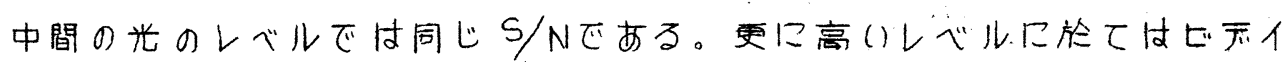
コンの方汃 $S / N$ はを()。てしてくら(時はイメージオルシコンの方が S/Nは大き()。この理由はビデイコンはS/Nが增巾蝈の入力雑音で決定 されるの界对し、イメージオルシコンの方は走查ビームのショット程 〔決定をれるからである。然し尚高感度の夕一尔ットが発明されっは， 如何なる光のレべルに於てもイメージオルション以上にする事加出爽る。

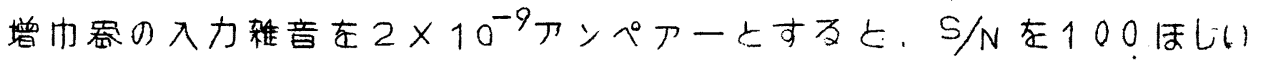
ためにはビーム軋流は0.2uA必要となる。これはイメージオルシコン のビーム電流の10倍に相当する。

カメラは16 $\mathrm{mm}$ 撮影機のレンズで充分である。 
* 1. I ams and. Roee.

"Television pick up Tuhes with cathods ray beam acanning."

$$
\text { P.T.R.E. 2.5. Auguet. } 1937
$$

*2. Miller and Ltrange.

"The Electrical reproduction of Images by the photo conductive effect."

$$
\text { proc. phing. Hoc, so p.374 } 1938 \text {. }
$$

* 3 Knoll and Schroter

"Transmission of pictures and signals by insulating and bemi conducting surface thesp.: $z$ is, p-s30, 1937.

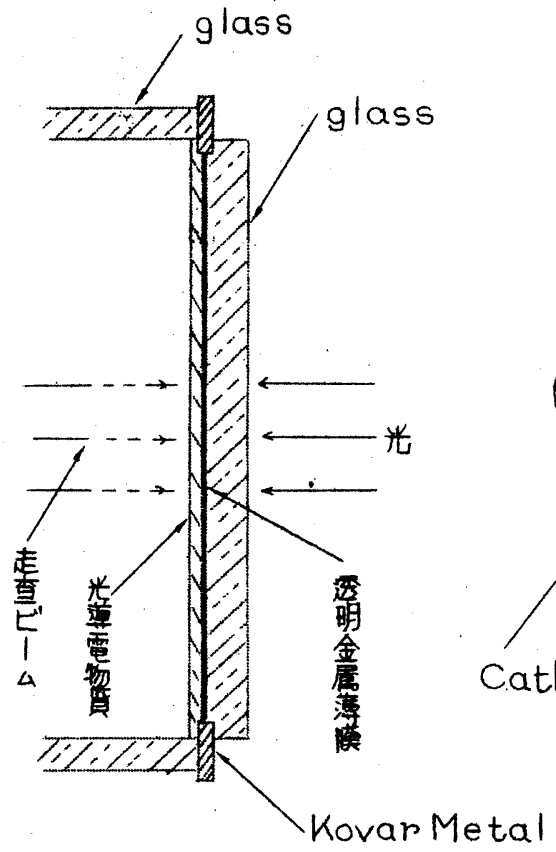

第 2 因

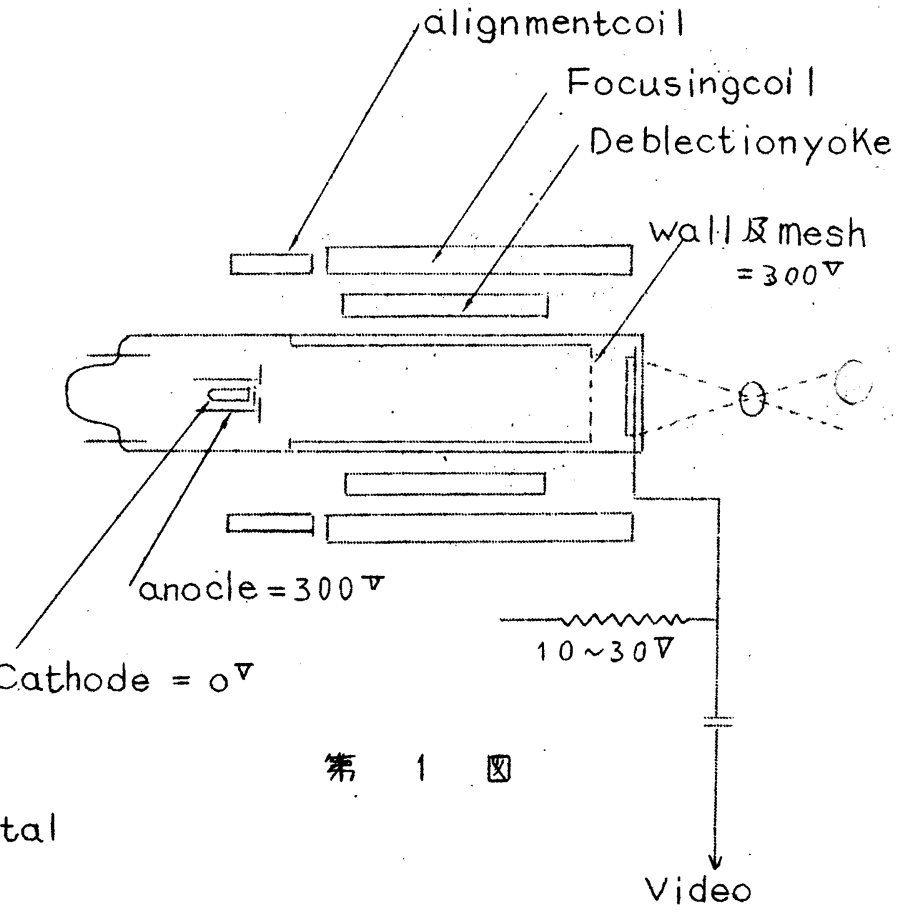

signal 